\title{
Europe's stem-cell workers pull together
}

\section{Federica Castellani, Munich}

As California gears up to become a world force in research on human embryonic stem cells, European scientists are banding together, buoyed by recent changes in Spanish and French law.

The European Stem Cell Network held its inaugural meeting in Seville, Spain, on 12 November. It brought together scientists from 14 European nations and Israel in a bid to promote collaboration.

"We clearly need a network in Europe," says meeting organizer Bernat Soria, director of the Institute of Bioengineering at Miguel Hernández University in Alicante. "Stemcell research is in its infancy - we want to collaborate and cooperate, not compete with each other, just now."

"In Europe we will never have the same resources as California will have," says Outi Hovatta, a stem-cell researcher at the Karolinska Institute in Stockholm. "But we are trying to reinforce ourselves by combining resources and experiences."

As if to set an example, Soria himself cemented a collaboration at the meeting. His group's diabetes research will be bolstered by new stem-cell lines from the Karolinska Institute.

Europe has been deeply divided over stem-cell research, but an increasing number of countries are permitting the work. Last month both Spain and France joined countries such as Britain and Sweden in passing laws to allow research on human embryonic stem cells.

Other nations remain opposed, however. German scientists, for example, much like their US colleagues outside California, can work only with first-generation stem-cell lines created before 1 January 2002. These older stem-cell lines are of limited use in front-line research, scientists complain.

"The legislative situation in Europe is very complicated," says Oliver Brüstle, a stem-cell researcher at the University of
Bonn. "But if we want to work internationally and exchange data we really need to be able to work with the same cell lines."

Scientists in the field agree that they need a single voice to speak to governments and put pressure on decision-makers for a common legislation. The new network, which will meet again in Edinburgh next March, could provide such a voice, says Soria.

And the need for common legislation is likely to become more acute - the European Commission's first explicit call for proposals for research involving human embryonic stem cells has just closed and funds could be forthcoming.

To secure funding from the commission, research projects have to involve multinational groups. But what the legal situation would be for a German scientist taking part in a project involving human embryonic stem cells has yet to be tested, Brüstle says. $\mathrm{He}$ adds that he will not work on any cell lines that are illegal in Germany.

\section{Grade expectations for German research institutes}

\section{Quirin Schiermeier, Munich}

To help students and researchers separate the wheat from the chaff, Germany's science council has proposed a rating system for the country's publicly funded research institutes.

At a meeting in Hamburg last week, the science council recommended that departments in up to $\mathbf{5 0}$ disciplines be regularly marked by independent experts. All German research organizations, including the Max Planck Society, have agreed to participate.

When fully established, probably in 2006, the ratings will be an easy way of comparing the strengths of different labs, says the science council.

Although the details have yet to be hashed out, grades are expected to be based on a seven-point scale and awarded once every five or six years. A department will receive the highest mark only if more than half of its research activities are considered to be of top international quality; the lowest mark will go to departments whose output falls below national standards. The science council is encouraging the development of both hard and soft indicators to be applied in varying degrees depending on the field, which should spare anthropologists and quantum physicists from being measured on the same criteria.

The ratings are likely to affect future funding decisions, but they are not meant to become the decisive factor. This will differentiate the system from one that

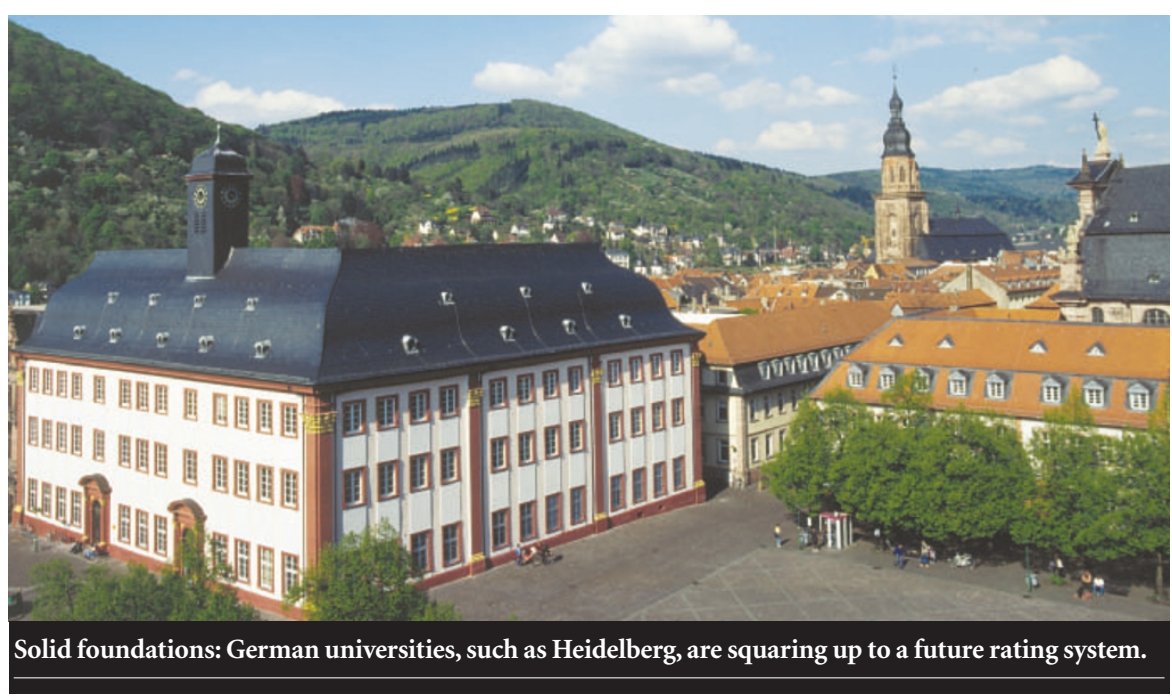

currently exists in Britain — the Research Assessment Exercise, which uses grading to assign some government grants.

The British audits are thought to have improved the competitiveness of UK research, but critics say they are excessively expensive and time-consuming, and tend to overemphasize quantitative indicators (see Nature 418, 6; 2002).

Similar objections are bubbling up in Germany. "Rankings are very popular among politicians and the public, but they are never objective, and sometimes they are even detrimental to science," says Wolfgang Baumeister, director of molecular structural biology at the Max Planck Institute for
Biochemistry in Martinsried, near Munich "They foster mainstream research and the hunt for short-term accomplishments instead of true innovation."

The proposal is being backed by the DFG, Germany's main funding agency. An institute will be created in Bonn to develop and test rating methodologies, and a pilot project designed to score sociology and informatics departments is scheduled to start in 2005.

For more news and analysis go to news@nature.com www.nature.com/news 